\title{
TCOM \\ On social change, agency, and public interest: what can science communication learn from public relations?
}

\section{Tara Roberson}

Abstract

Keywords

DOI

Introduction
This essay explores the relationship of science communication and public relations and contends that science communication has something to learn from public relations research. I provide an alternate history of public relations, drawn from the history of social movements (activism). I outline two areas from public relations theory: first, notions of human agency and equity in communication and, second, public interest in public communication. In doing so, I highlight how research from critical public relations could contribute to science communication efforts to enable participation with science and technology from wider, more diverse publics.

Participation and science governance; Public engagement with science and technology

https://doi.org/10.22323/2.19020401

Submitted: 10th September 2019

Accepted: 7th April 2020

Published: 20th April 2020

Part of the historical impetus for science communication in Australia was motivated by a desire to make "science more widely understood, more generously and wisely supported, more directly beneficial to the nation, and more accountable to the public interest" [Gascoigne and Metcalfe, 2017; MacLeod, 1998, p. xi]. The motivations for science communication are similarly described by aims to: enhance public understanding, make science accessible, secure ongoing political support, and democratically account for use of public funds and enable public participation in the processes of science and technology [Weingart and Joubert, 2019]. From these broad motivations, it seems that the 'public interest' of science communication rests on the assumption that science, and therefore science communication, is "oriented towards the common good and transcends political ideologies and/or economic interests" [Weingart and Guenther, 2016].

As Irwin and Horst argue, this conception of the public interest of science and science communication is an obvious over-generalisation [2016]. Indeed, "it is difficult to accept that science is by its very nature 'the ultimate reference... when reliable knowledge is at stake"' [Irwin and Horst, 2016, pp. 1-2]. This leaves the 
public interest of science communication still up for discussion. In this essay, I seek to expand on this topic by drawing on literature from a related field, public relations. Trench and Bucchi have already argued that "science communication [can] benefit more from a clearer articulation and deeper exploration of its relations with its neighbours than from further insistence on its separateness and uniqueness" [2010, p. 4]. With this perspective in mind, I highlight science communication critiques of public relations in science. I present literature from public relations to challenge the idea that public relations is solely concerned with corporate, promotional communication. Following this, I briefly address two challenges shared by public relations and science communication: first, the issue of human agency and (in)equity in public communication and, second, the place of public interest in these disciplines. Here, I identify where science communication might learn from public relations research.

\section{Science communication on public relations}

Science communication scholars can be rather critical of the capacity of public relations to contribute to their field. These critical perspectives tend to argue that strategic, 'corporate-ised' communication - in particular, public relations - undermines the value and communicative standards of science and science journalism. For instance, Dorothy Nelkin's work Selling Science argues that public relations exploits journalism [1995]. Similarly, Weingart and Guenther [2016] contend that science communication in modern society has been tainted by 'interests', the use of persuasive communication, and the use of science PR to produce "institutional propaganda" (p. 4). Meanwhile, Bauer and Gregory's work From journalism to corporate communication concludes that a post-war shift in research funding prompted corporate-style communication, which moved science communication from a more journalistic approach (using investigation, education, and enlightenment) to strategic public relations [2008]. Implicit in this work is the argument that public relations will focus on more promotional and less critical science media coverage. In science communication more broadly the object of this line of criticism is often the press release [Sumner et al., 2016], which is held up at the epitome of simplification and exaggeration.

In response to this critique of public relations, I contend that science communication has something to learn from public relations and that, in fact, public relations and science communication share many common features. Public relations definitions can vary, but at their core they are chiefly concerned with strategic relationship management and communication [Johnston, 2016; Moloney, 2006]. As public relations scholar Johnstone argues, public relations, like science communication, is "part of civil society, involved in organised activism, and more dependent on function and skill than titled PR operators" [2016, p. 2].

Both public relations and science communication seek to engage and inform their publics. Scholars in both disciplines produce individual case studies of engagement and outreach, chart the evolution of practitioners' roles, and trace the impact of communication strategies [Burns, O'Connor and Stocklmayer, 2003; Nisbet and Scheufele, 2009; Solis and Breakenridge, 2009; Treadwell and Treadwell, 2005]. In practise, public relations and science communication-focused roles within research institutions can sit side-by-side and, even, share functions [Autzen, 2014; 
Autzen and Weitkamp, 2019; Shipman, 2014]. Despite public relations contributing to the communicative ecosystem of science and technology [Borchelt and Nielsen, 2014], public relations sceptics tend to view the field as solely concerned with manipulation and hype [Bauer and Gregory, 2008; Elsner, 2014]. In this essay, I suggest that there is more to consider when it comes to public relations in science.

Public relations and the history of social movements
For science communicators, public relations literature contains some familiar stories: individual case studies, social media campaigns, and debate over best practice [L'Etang, Coombs and Xifra, 2014]. This literature is also the place where we find reflexive and, in some cases, conflicting accounts on the purpose and the evolution of the field.

Miller [2000] contends that public relations scholars should pay more attention to the public relations of social movements, also known as activism. Indeed, Lamme [2003] argues, before corporate public relations began, public relations was used in the name of "public-sentiment building" work by the Anti-Saloon League of America. These anti-saloon groups were the very activists that corporates began to respond to by co-opting their tactics [Coombs and Holladay, 2012b]. The activists had communications plans "largely in place long before oft-cited public relations pioneers such as Edward Bernays and John Hill began practicing" [Lamme, 2003, p. 123]. Some scholars believe that activists have continued this dynamic of being early adopters in public relations today by pioneering the use of new media, for instance the use of social media channels to threaten reputations and leverage change [Coombs, 2002; Coombs and Holladay, 2007]. Moreover, a study from Russell and Lamme that examined global public relations prior to 1900 found that "corporations and agencies were neither the creators nor even the culmination of the field's development" [2016, p. 742]. These scholars argue that the primary drivers of public relations were institutions (e.g. non-profits and government) and individuals.

We could, therefore, propose a different way of framing public relations as not simply the domain of large organisations but also as part of activism, or creating social change [Coombs and Holladay, 2012a]. As well as diversifying the type of work done by public relations, the public relations of social movements can contribute to the interests of science communication. For instance, the move to communication driven by a democratic imperative of engagement with science and technology, which must be dialogic and should occur 'upstream' where new science and technology is being created [Borschelt, 2008; Nisbet and Scheufele, 2009; Wynne, 2006]. Stakeholders must possess a meaningful ability to comment on ownership, regulation, uses, benefits and risks if the communicative activity is to be truly participative and not another form of deficit model outreach [Nisbet and Scheufele, 2009; Stilgoe and Guston, 2017]. In a similar vein, public relations academic Grunig writes that communicators "must consistently remind themselves and management that they might not be right, and, indeed, that their organisations might be better off if they listen to others" [2000, p. 28]. While this recommendation is by no means uniformly adopted, it remains important to view public relations - and, I would argue, science communication - activities in relation to theories of social justice and citizenship to "encourage more accountable and empowering communicative practices" [Demetrious, 2013, p. 4]. 
Heath argues that "we need a paradigm of public relations that features it as being capable of adding value to the full (sic) functioning society" [2006, p. 95]. This paradigm would acknowledge that organisations - including universities and research institutes - engage in and have a need for public relations. Here, public relations looks to the good of society, rather than the individual or organisation, and contributes to responsiveness and inclusivity [Brown, 2014]. Johnston contends that this role should be concerned with access and equality [2016, p. 62] while Moloney defines it as "a correction to the historically observed PR condition of unequal distribution of communicative resources amongst interests in actual liberal democracy" [Moloney, 2006, p. 170].

For science communication, this paradigm of public relations might help convene publics and invite the contribution of different perspectives. This could assist science and technology actors looking to "learn from disagreement and avoid common communication mistakes that undermine these goals" [Nisbet and Scheufele, 2009, p. 95]. Holtzhausen's [2000] postmodern analysis public relations also claims that public relations should be freed from its narrow definition of corporate communication because of the field's ability to contribute to grassroots democracy, activism, and radical politics. This analysis contends that, in a world defined by continuous change, public relations presents a way of activating and defining that change in addition to providing a voice for communities. For science communication, public relations might provide a way to connect with audiences beyond the elite, science-enthusiast groups typically attracted by science communication activities [Scheufele and Brossard, 2008; Tichenor, Donohue and Olien, 1970].

In this sense, science communication as public relations can contribute more than the merely celebratory, uncritical, and myth-making contributions anticipated by Bauer and Gregory. Publics, then, would be more than consumers; instead they become active citizens able to participate in discussions over developments that affect their lives. Here, the public forum is not a trade show but a real change for participation and dialogue, which includes respectful debate and a chance to learn from disagreement.

Agency and (in)equity
L'Etang defines public relations as "communication and the exchange of ideas either in response to or to facilitate change" [2008, p. 18]. The inclusion of 'exchange' with this definition reflects the use of dialogue or two-way communication, which is designed to achieve mutual understanding instead of one-way persuasion [Grunig and Toth, 2006].

These perspectives on public relations draw on two basic features, presented by Russell and Lamme [2016] as the best way to identify public relations activity. These public relations scholars write that, first, we should consider the strategic intent of practitioners. In other words, public relations activity can be identified by investigating whether "communication tactics are employed with a specific outcome in mind, and [where] activities are not random, but actively selected based on the results a communicator hopes to achieve" [Russell and Lamme, 2016, p. 744]. The second feature is human agency. Here, audiences of persuasive messages must have a choice in how they respond to those messages. This allows us to differentiate between public relations and propaganda. Taylor and Kent 
[2014] emphasis this distinction through their continuum of persuasion, which starts with propaganda and moves through to dialogue. On this continuum, public relations is closest to dialogue and distant from propaganda, which is highly strategic and allows for little to no human agency [see also L'Etang, 2008]. This essential combination of agency and intent draws on the rhetorical heritage of public relations as no communicative act can be truly effective without knowing, appreciating, and respecting what others believe and think, and why they hold those positions [Heath, 2014]. As a result, practitioners in the message and meaning business (here, science communicators and public relations practitioners) cannot be narrowly focused on the self-interest and opinions of the group they represent [Priest, Goodwin and Dahlstrom, 2018]. Public relations is about working to create dialogue [Kent and Taylor, 1998] whilst competing for time and space amongst multiple voices. In this competition, publics have the right and ability to obtain and judge messages and make decisions. Meanwhile, through dialogue, individuals and groups can co-create and negotiate identity, interest, and socially relevant meaning [Heath, 2014; Mead, 1934], which is vital in any context which requires individuals to make a choice [Nichols, 1963].

There is an inescapable link between democratic decision-making and communication. Communication, including public relations, carries ideas "out in the open" and enables participation by people from all walks of life [Barnett, 2008, p. 3]. Barnett [2008] contends that "democracy acquires its value not just by embodying the preferences or will of the many, but also by involving free and open discussion and debate" (p. 3). In this sense of democratic publicness, publics are created or convened by claims to either speak on their behalf or act in their interest. These publics come together because they concur, disagree, or otherwise react to such claims [Roberson, 2020]. Public relations is part of this process in creating and conveying these claims and, ideally, facilitating responses. With calls for "more active, open and democratic relations" between science and citizens, public engagement for science needs to become much more than consensus building exercise [Irwin, 2008, p. 200]. In addition, science and technology actors need to frame their messages in a way to activate participation from "wider, more diverse and otherwise inattentive publics" [Nisbet and Scheufele, 2009, p. 1770]. Public relations' positioning of the importance of agency represents an opportunity for rethinking how these aims might be achieved.

Another feature that is closely related to human agency, and which critical public relations theory highlights, is equity, or a lack thereof in communicative processes [Demetrious, 2013]. Public communication within the context of this essay is a contest of ideas. This contest asks decision makers and publics to justify reasoning and positions [Johnston, 2016]. However, communicative resources are unevenly applied. For instance, access to platforms for discussion and communications practitioners is by no means guaranteed. The equity of these processes informs human agency and seems as challenging for science communication as public relations with a recent Journal of Science Communication special issue on feminist theory highlighting the way science communicators sit "at an intersection between dominant and marginalised perspectives. [And] ... often in positions of privilege and power" [Halpern, 2019, p. 3]. These intersections of perspective and privilege require communicators to learn from marginalised publics and consider how communication practices do or do not account for diversity, inequity, and public interest. While science communication presents some initial options for breaking 
away from restrictive, defined roles and preventing the privileging of information flow [Horst and Michael, 2011], both fields could yet benefit from the use of a critical feminist, also known as relational ethics, lens [Halpern, 2019; Medvecky and Leach, 2019].

Public interest and public communication
Viewing public relations in terms of its contributions to activism and views on human agency and equity is one way of challenging the assumption that public relations is corporate-centric, focused on propaganda and the promotion of special interest groups. More recent, critical public relations theory contributes an alternative way for understanding of how public relations can contribute to a fully functioning society.

Johnston contends that public relations - with its roles in policy creation, governance, and public communication - can productively engage with public interest. Here, public relations can use public interest "as a reflexive tool... to better understand itself and its place in society" [Johnston, 2016, p. 3]. This need to reflect on and engage with public interest seems be recognised by professionals, as well as academics, within the field. Inside the last decade, professional public relations bodies have redefined their definitions of public relations in terms of public interest. For instance, the Canadian Public Relations Society has come to define public relations as:

\begin{abstract}
"Public relations is the strategic management of relationships between an organisation and its diverse publics, through the use of communication, to achieve mutual understanding, realise organisational goals, and serve the public interest."
\end{abstract}

This shift provides a "litmus test of how scholars and industry view [public interest's] relevance" [Johnston, 2016, p. 17].

One of the key contributions of public interest to critical public relations theory is the way it prompts "correction to the historically observed PR condition of unequal distribution of communicative resources among interests in actual liberal democracy" [Moloney, 2006, p. 170]. In providing this prompt, public interest articulates a tension between the role of public relations practitioners as serving self- and organisational- interest at the same time as contributing to public good on a societal level. This tension between different interests is articulated by Bivins [1993, pp. 120-124] who proposed four public interest paradigms:

Paradigm I: If every individual practicing public relations acts in the best interest of their client, then the public interest will be served.

Paradigm II: If, in addition to serving individual interests, an individual practicing public relations serves public interest causes, the public interest will be served

Paradigm III: If a professional or professionals assure that every individual in need or desiring public relations services receives those services, then the public interest will be served 
Paradigm IV: If public relations as a professional improves the quality of debate over issues important to the public, then the public interest will be served

Bivins suggests the last paradigm is the most achievable and contends that public relations has a responsibility to fulfil its roles as 'mediator and advocate' by engaging in and encourages public debate.

These tensions between the duty of the communication practitioner to their self, the organisation, and society brings useful insights to science communication. As Weingart and Joubert [2019] have previously found, there are a range of motivations for science communication. Science communicators can both promote and advocate for science while encouraging two-way dialogue and engagement between science and society [Raman et al., 2018]. These motivations prompt tensions for the practitioners doing science communication as they are split between their own interests and those of the organisation they might work for, in addition to the broader drive of the field to make "science more open, more democratic" [Medvecky and Leach, 2019, p. 37]. Johnston argues that incorporating public interest in public relations "can not only provide balance in discourse and decision making, but also can raise levels of public understanding, knowledge and participation" [Johnston, 2016, p. 20]. This contention rests on the use of public interest to motivate engagement with publics and individuals who are outside of the 'usual' process to ensure that notions of the public interest and, consequently, acts of public communication reflect diverse social interests.

\section{Science communication and public relations}

This essay presents three key insights from public relations research that could add to science communication efforts, particularly those aimed at enabling participation by wider, more diverse publics with science and technology processes. The first insight reframed public relations by emphasising its connection to communication for social change. The act of communicating in this perspective both invites and listens to responses from publics. The second insight drew on notions of human agency and equity. In public relations, human agency ensures that audiences have a choice in how they respond to communication, meanwhile equity prompts us to consider how acts of communication do (or do not) account for diverse perspectives and differing privilege. The third and final insight reviewed notions of public interest in relation to public communication to illuminate tensions between the duty of communications practitioners to their self, the organisation, and society.

Both public relations and science communication seek to reach publics who are, in some sense, linked with the issue at hand. Practitioners in each field work to build relationships, foster dialogue, and facilitate responses from publics. By doing so, through specifically designed communication activities and with key outcomes in mind, they are unquestionably driven by strategic intent. And, in turn, their audiences are possessed with clear agency - the ability to concur or not with the messages at hand. Publics may then come together because they concur, disagree, or otherwise react to claims [Barnett, 2008]. Science communication and public relations work within what could be termed an 'overcommunicated' society; practitioners in this space can struggle to attract the attention and engagement necessary to enable proper dialogue and interaction from relevant publics. In the context of that struggle, enforcing an unnecessary division between science communication and public relations does a disservice as we ignore the wealth of information possessed by our neighbours. 
Autzen, C. (2014). 'Press releases - the new trend in science communication'. JCOM 13 (03), C02. URL: https://jcom.sissa.it/archive/13/03/JCOM_1303_2 014_C01/JCOM_1303_2014_C02.

Autzen, C. and Weitkamp, E. (2019). '22. Science communication and public relations: beyond borders'. In: Handbook of Science Communication. Ed. by A. Leßmöllmann, M. Dascal and T. Gloning. Vol. 17. Berlin, Germany: De Gruyter, pp. 465-484. https://doi.org/10.1515/9783110255522-022.

Barnett, C. (2008). 'Convening publics: the parasitical spaces of public action'. In: The SAGE Handbook of Political Geography. Ed. by K. R. Cox, L. Murray and J. Robinson. U.K.: SAGE Publications Ltd, pp. 403-418. https://doi.org/10.4135/9781848607880.n25.

Bauer, M. W. and Gregory, J. (2008). 'From journalism to corporate communication in post-war Britain'. In: Journalism, science and society: science communication between news and public relations. Ed. by M. W. Bauer and M. Bucchi. New York, NY, U.S.A.: Routledge. https: //doi . org/10.4324/9780203942314.

Bivins, T. H. (1993). 'Public relations, professionalism and the public interest'. Journal of Business Ethics 12 (2), pp. 117-126. https://doi.org/10.1007/bf00871931.

Borchelt, R. E. and Nielsen, K. H. (2014). 'Public relations in science: managing the trust portfolio'. In: Routledge Handbook of Public Communication of Science and Technology. Ed. by M. Bucchi and B. Trench. 2nd ed. London, U.K. and New York, U.S.A.: Routledge, pp. 58-69. https://doi.org/10.4324/9780203483794.

Borschelt, R. (2008). 'Public relations in science: managing the trust portfolio'. In: Handbook of Public Communication of Science and Technology. Ed. by M. Bucchi and B. Trench. London, U.K. and New York, U.S.A.: Routledge, pp. 147-158.

Brown, R. E. (2014). The public relations of everything: the ancient, modern and postmodern dramatic history of an idea. U.K.: Routledge. https://doi.org/10.4324/9780203082751.

Burns, T. W., O'Connor, D. J. and Stocklmayer, S. M. (2003). 'Science Communication: A Contemporary Definition'. Public Understanding of Science 12 (2), pp. 183-202. https://doi.org/10.1177/09636625030122004.

Coombs, W. T. and Holladay, S. J. (2007). It's not just PR: public relations in society. Malden, MA, U.S.A.: Blackwell Publishing.

Coombs, W. T. (2002). 'Assessing online issue threats: issue contagions and their effect on issue prioritisation'. Journal of Public Affairs 2 (4), pp. 215-229. https://doi.org/10.1002/pa.115.

Coombs, W. T. and Holladay, S. J. (2012a). 'Fringe public relations: how activism moves critical PR toward the mainstream'. Public Relations Review 38 (5), pp. 880-887. https://doi.org/10.1016/j. pubrev.2012.02.008.

- (2012b). 'Privileging an activist vs. a corporate view of public relations history in the U.S.' Public Relations Review 38 (3), pp. 347-353. https://doi.org/10.1016/j.pubrev.2011.11.010.

Demetrious, K. (2013). Public relations, activism and social change: speaking up. New York, NY, U.S.A.: Routledge. https : //doi . org/10.4324/9780203078440.

Elsner, G. (2014). 'Using public relations to defy science'. Journal of Mass Media Ethics 29 (2), pp. 131-134. https://doi.org/10.1080/08900523.2014.893780. 
Gascoigne, T. and Metcalfe, J. (2017). 'The emergence of modern science communication in Australia'. JCOM 16 (03), A01. URL: https://jcom.sissa.it/archive/16/03/JC0M_1603_2017_A01.

Grunig, J. E. (2000). 'Collectivism, collaboration and societal corporatism as core professional values in public relations'. Journal of Public Relations Research 12 (1), pp. 23-48. https://doi.org/10.1207/s1532754xjprr1201_3.

Grunig, L. A. and Toth, E. L. (2006). 'The ethics of communicating with and about difference in a changing society'. In: Ethics in public relations: responsible advocacy. Ed. by K. Fitzpatrick and C. Bronstein. Thousand Oaks, CA, U.S.A.: SAGE Publications, Inc., pp. 39-52. https://doi.org/10.4135/9781452204208.n3.

Halpern, M. (2019). 'Feminist standpoint theory and science communication'. JCOM 18 (04), C02. https: //doi .org/10.22323/2.18040302.

Heath, R. L. (2014). Rhetorical and critical approaches to public relations II. U.S.A.: Taylor and Francis.

Heath, R. L. (2006). 'Onward into more fog: thoughts on public relations' research directions'. Journal of Public Relations Research 18 (2), pp. 93-114. https://doi.org/10.1207/s1532754xjprr1802_2.

Holtzhausen, D. R. (2000). 'Postmodern values in public relations'. Journal of Public Relations Research 12 (1), pp. 93-114. https://doi.org/10.1207/s1532754xjprr1201_6.

Horst, M. and Michael, M. (2011). 'On the shoulders of idiots: re-thinking science communication as 'event'. Science as Culture 20 (3), pp. 283-306. https://doi.org/10.1080/09505431.2010.524199.

Irwin, A. (2008). 'Risk, science and public communication: Third-order thinking about scientific culture'. In: Handbook of Public Communication of Science and Technology. Ed. by M. Bucchi and B. Trench. London, U.K. and New York, U.S.A.: Routledge, pp. 199-212.

Irwin, A. and Horst, M. (2016). 'Communicating trust and trusting science communication - some critical remarks'. JCOM 15 (06), L01. https://doi.org/10.22323/2.15060101.

Johnston, J. (2016). Public relations and the public interest. New York, NY, U.S.A.: Routledge. https://doi.org/10.4324/9781315737034.

Kent, M. L. and Taylor, M. (1998). 'Building dialogic relationships through the world wide web'. Public Relations Review 24 (3), pp. 321-334. https://doi.org/10.1016/s0363-8111(99)80143-x.

L'Etang, J. (2008). 'Writing PR history: issues, methods and politics'. Journal of Communication Management 12 (4), pp. 319-335. https://doi.org/10.1108/13632540810919783.

L'Etang, J., Coombs, W. T. and Xifra, J. (2014). 'Editorial'. Public Relations Inquiry 3 (3), pp. 269-270. https://doi.org/10.1177/2046147x14550742.

Lamme, M. O. (2003). 'The "public sentiment building society": the anti-saloon league of America'. Journalism History 29 (3), pp. 123-132. https://doi.org/10.1080/00947679.2003.12062629.

MacLeod, R. (1998). The commonwealth of science: ANZAAS and the scientific enterprise in Australia 1888-1988. Australia: Oxford University Press.

Mead, G. H. (1934). Mind, self and society. Chicago, IL, U.S.A.: University of Chicago Press. 
Medvecky, F. and Leach, J. (2019). An ethics of science communication. Cham, Switzerland: Palgrave Pivot. https://doi.org/10.1007/978-3-030-32116-1.

Miller, K. S. (2000). 'U.S. public relations history: knowledge and limitations'. Annals of the International Communication Association 23 (1), pp. 381-420. https://doi.org/10.1080/23808985.2000.11678978.

Moloney, K. (2006). Rethinking public relations. London, U.K.: Routledge.

Nelkin, D. (1995). Selling science: how the press covers science and technology. New York, NY, U.S.A.: W.H. Freeman.

Nichols, M. H. (1963). Rhetoric and criticism. Baton Rouge, LA, U.S.A.: Louisiana State University Press.

Nisbet, M. C. and Scheufele, D. A. (2009). 'What's next for science communication? Promising directions and lingering distractions'. American Journal of Botany 96 (10), pp. 1767-1778. https://doi.org/10.3732/ajb.0900041.

Priest, S., Goodwin, J. and Dahlstrom, M. F. (2018). Ethics and practice in science communication. Chicago, IL, U.S.A.: University of Chicago Press.

Raman, S., Hobson-West, P., Lam, M. E. and Millar, K. (2018). "Science matters' and the public interest: the role of minority engagement'. In: Science and the politics of openness: here be monsters. Ed. by B. Nerlich, S. Hartley, S. Raman and A. Smith. Manchester, U.K.: Manchester University Press. https://doi.org/10.7765/9781526106476.00022.

Roberson, T. (2020). 'Can hype be a force for good? Inviting unexpected engagement with science and technology futures'. Public Understanding of Science. Forthcoming.

Russell, K. M. and Lamme, M. O. (2016). 'Theorizing public relations history: the roles of strategic intent and human agency'. Public Relations Review 42 (5), pp. 741-747. https://doi.org/10.1016/j.pubrev. 2016.04.002.

Scheufele, D. A. and Brossard, D. (2008). Nanotechnology as a moral issue? Religion and science in the U.S. American Association for the Advancement of Science, Professional Ethics Report, 21, pp. 1-3.

Shipman, M. (2014). 'Public relations as science communication'. JCOM 13 (03), C05. https://doi.org/10.22323/2.13030305.

Solis, B. and Breakenridge, D. K. (2009). Putting the public back in public relations. U.S.A.: FT Press.

Stilgoe, J. and Guston, D. H. (2017). 'Responsible research and innovation'. In: The handbook of science and technology studies. Ed. by U. Felt, R. Fouche, C. A. Miller and L. Smith-Doerr. 4th ed. Cambridge, MA, U.S.A.: The MIT Press.

Sumner, P., Vivian-Griffiths, S., Boivin, J., Williams, A., Bott, L., Adams, R., Venetis, C. A., Whelan, L., Hughes, B. and Chambers, C. D. (2016).

'Exaggerations and caveats in press releases and health-related science news'. PLOS ONE 11 (12), e0168217. https://doi.org/10.1371/journal. pone.0168217.

Taylor, M. and Kent, M. L. (2014). 'Dialogic engagement: clarifying foundational concepts'. Journal of Public Relations Research 26 (5), pp. 384-398. https://doi.org/10.1080/1062726x.2014.956106.

Tichenor, P. J., Donohue, G. A. and Olien, C. N. (1970). 'Mass media flow and differential growth in knowledge'. Public Opinion Quarterly 34 (2), p. 159. https://doi.org/10.1086/267786. 
Treadwell, D. and Treadwell, J. B. (2005). Public relations writing: principles in practice. U.S.A.: SAGE Publications.

Trench, B. and Bucchi, M. (2010). 'Science communication, an emerging discipline'. JCOM 09 (03), C03. https://doi .org/10.22323/2.09030303.

Weingart, P. and Guenther, L. (2016). 'Science communication and the issue of trust'. JCOM 15 (05), C01. URL: http://jcom.sissa.it/archive/15/05/JCOM_1 505_2016_C00/JCOM_1505_2016_C01.

Weingart, P. and Joubert, M. (2019). 'The conflation of motives of science communication - causes, consequences, remedies'. JCOM 18 (03), Y01. https://doi.org/10.22323/2.18030401.

Wynne, B. (2006). 'Public Engagement as a Means of Restoring Public Trust in Science - Hitting the Notes, but Missing the Music?' Community Genetics 9 (3), pp. 211-220. https://doi.org/10.1159/000092659.

Author

Tara Roberson is a postdoctoral research fellow in responsible innovation and science communication at the Australian Research Council Centre of Excellence for Engineered Quantum Systems. She recently completed her PhD at Australia's National Centre for Public Awareness of Science. E-mail: t.roberson@uq.edu.au.

How to cite

(C) The Author(s). This article is licensed under the terms of the Creative Commons Attribution - NonCommercial - NoDerivativeWorks 4.0 License.

ISSN 1824-2049. Published by SISSA Medialab. jcom.sissa.it 